\title{
Isotopic signatures reveal zinc cycling in the natural habitat of hyperaccumulator Dichapetalum gelonioides subspecies from Malaysian Borneo
}

Antony van der Ent ${ }^{1,2}$, Philip Nti Nkrumah" ${ }^{1 *}$, Mark G. M. Aarts ${ }^{3}$, Alan J. M. Baker ${ }^{1,2,4}$, Fien Degryse ${ }^{5}$, Chris Wawryk ${ }^{6}$ and Jason K. Kirby ${ }^{6}$

\begin{abstract}
Background: Some subspecies of Dichapetalum gelonioides are the only tropical woody zinc (Zn)-hyperaccumulator plants described so far and the first Zn hyperaccumulators identified to occur exclusively on non-Zn enriched 'normal' soils. The aim of this study was to investigate $\mathrm{Zn}$ cycling in the parent rock-soil-plant interface in the native habitats of hyperaccumulating Dichapetalum gelonioides subspecies (subsp. pilosum and subsp. sumatranum). We measured the $\mathrm{Zn}$ isotope ratios $\left(\delta^{66} \mathrm{Zn}\right)$ of Dichapetalum plant material, and associated soil and parent rock materials collected from Sabah (Malaysian Borneo).

Results: We found enrichment in heavy $\mathrm{Zn}$ isotopes in the topsoil $\left(\delta^{66} \mathrm{Zn} 0.13 \%\right.$ ) relative to deep soil $\left({ }^{66} \mathrm{Zn}-0.15\right.$ $\% 0)$ and bedrock ( ${ }^{66} \mathrm{Zn}-0.90 \%$ ). This finding suggests that both weathering and organic matter influenced the $\mathrm{Zn}$ isotope pattern in the soil-plant system, with leaf litter cycling contributing significantly to enriched heavier $\mathrm{Zn}$ in topsoil. Within the plant, the roots were enriched in heavy $\mathrm{Zn}$ isotopes $\left(\delta^{66} \mathrm{Zn} \sim 0.60 \%\right.$ ) compared to mature leaves $\left(\delta^{66} \mathrm{Zn} \sim 0.30 \%\right.$ ), which suggests highly expressed membrane transporters in these Dichapetalum subspecies preferentially transporting lighter $\mathrm{Zn}$ isotopes during root-to-shoot translocation. The shoots, mature leaves and phloem tissues were enriched in heavy $\mathrm{Zn}$ isotopes ( $\delta^{66} \mathrm{Zn} 0.34-0.70 \%$ ) relative to young leaves $\left(\delta^{66} \mathrm{Zn} 0.25 \%\right.$ ). Thisindicates that phloem sources are enriched in heavy $\mathrm{Zn}$ isotopes relative to phloem sinks, likely because of apoplastic retention and compartmentalization in the Dichapetalum subspecies.

Conclusions: The findings of this study reveal $\mathrm{Zn}$ cycling in the rock-soil-plant continuum within the natural habitat of $\mathrm{Zn}$ hyperaccumulating subspecies of Dichapetalum gelonioides from Malaysian Borneo. This study broadens our understanding of the role of a tropical woody Zn hyperaccumulator plant in local Zn cycling, and highlights the important role of leaf litter recycling in the topsoil Zn budget. Within the plant, phloem plays key role in Zn accumulation and redistribution during growth and development. This study provides an improved understanding of the fate and behaviour of $\mathrm{Zn}$ in hyperaccumulator soil-plant systems, and these insights may be applied in the biofortification of crops with Zn.
\end{abstract}

Keywords: Cycling, Hyperaccumulation, Phloem, Southeast Asia, Weathering, Zinc isotopes

\footnotetext{
* Correspondence: p.nkrumah@uq.edu.au

${ }^{1}$ Centre for Mined Land Rehabilitation, Sustainable Minerals Institute, The University of Queensland, Queensland 4072 St Lucia, Australia

Full list of author information is available at the end of the article
}

(C) The Author(s). 2021 Open Access This article is licensed under a Creative Commons Attribution 4.0 International License, which permits use, sharing, adaptation, distribution and reproduction in any medium or format, as long as you give appropriate credit to the original author(s) and the source, provide a link to the Creative Commons licence, and indicate if changes were made. The images or other third party material in this article are included in the article's Creative Commons licence, unless indicated otherwise in a credit line to the material. If material is not included in the article's Creative Commons licence and your intended use is not permitted by statutory regulation or exceeds the permitted use, you will need to obtain permission directly from the copyright holder. To view a copy of this licence, visit http://creativecommons.org/licenses/by/4.0/ The Creative Commons Public Domain Dedication waiver (http://creativecommons.org/publicdomain/zero/1.0/) applies to the data made available in this article, unless otherwise stated in a credit line to the data. 


\section{Background}

Metal hyperaccumulator plants have the ability to accumulate high concentrations of potentially toxic trace elements in their living shoots without suffering any toxicity symptom (Baker and Brooks 1989; Reeves 2003; Reeves et al. 2018). For zinc ( $\mathrm{Zn})$, the notional hyperaccumulation threshold is set at $3000 \mu \mathrm{g} \mathrm{g}^{-1}$ (Krämer et al. 2007; van der Ent et al. 2013). This contrasts with Zn concentrations in most non-hyperaccumulator plant species that are typically between 30 and $100 \mu \mathrm{g} \mathrm{g}^{-1}$ (Nouvas et al. 2018). Zinc hyperaccumulator plants are a minority $(\sim 30$ species $)$ of the $\sim 700$ hyperaccumulator plant species currently documented globally (Reeves et al. 2018). All Zn hyperaccumulator species that have been identified to date are herbaceous plants, except for some subspecies of Dichapetalum gelonioides, which is a (tropical) woody species (Nkrumah et al. 2018). All herbaceous $\mathrm{Zn}$ hyperaccumulators only hyperaccumulate $\mathrm{Zn}$ when growing in Zn-rich metalliferous soils, with the notable exception of Arabidopsis halleri and several Noccaea species (notably N. caerulescens) which occur on both Zn-rich and non-contaminated soils and hyperaccumulate on both. The foliar tissues of $A$. halleri and $N$. caerulescens can accumulate 53,900 and 12,300 $\mu \mathrm{g} \mathrm{Zn}$ $\mathrm{g}^{-1}$, respectively, when growing on uncontaminated 'normal' soils with $<350 \mu \mathrm{g} \mathrm{Zn} \mathrm{g}^{-1}$ (Tang et al. 2012; Stein et al. 2017). Arabidopsis halleri and N. caerulescens are the two key model species for the study of $\mathrm{Zn}$ hyperaccumulation and their ecology, physiology, molecular biology and genetics have broadened our understanding of metal regulation in plants (Bert et al. 2000; Assunção et al. 2003; Schwartz et al. 2003; Lin et al. 2014; Stein et al. 2017; Ricachenevsky et al. 2021).

Zinc hyperaccumulator plants take up $\mathrm{Zn}$ from the same $\mathrm{Zn}$ labile soil pools as non-hyperaccumulator plants, but at higher rates (Deng et al. 2014). Zinc transport within plants occurs by means of several families of metal transporters, and the hyperaccumulation trait likely evolved from mechanisms involved in the regulation of Zn homeostasis (Ajeesh Krishna et al. 2017; Corso and García de la Torre 2020; Hanikenne and Nouet 2011; Manara et al. 2020). The Zn hyperaccumulation trait is correlated with high and constitutive expression of genes normally involved in the $\mathrm{Zn}$ deficiency response, such as in metal transport, in the biosynthesis of metal chelators and in cellular defences to oxidative stresses (Andresen et al. 2018; Assunção et al. 2001; Hammond et al. 2006; van de Mortel et al. 2006; Talke et al. 2006; Hanikenne and Nouet 2011). The current hypothesis is evolution of $\mathrm{Zn}$ hyperaccumulation likely resulted from an increased uptake of $\mathrm{Zn}$ by roots (Cappa and Pilon-Smits 2014; Hanikenne and Nouet 2011; Merlot et al. 2021). These plants then translocate the $\mathrm{Zn}$ to the shoots and sequester it in foliar cells, which provide a selective advantage through protection against herbivory (Boyd 2012; Boyd and Martens 1994; Cabot et al. 2019; Pollard and Baker 1997; Stolpe et al. 2017). Thereafter, in subsequent cycles of selection, hyperaccumulation evolved to become more efficient by improving $\mathrm{Zn}$ translocation and shoot sequestration or detoxification (Assunção et al. 2001; Lin et al. 2014; Schvartzman et al. 2018).

The mechanisms underlying $\mathrm{Zn}$ hyperaccumulation are still far from being fully understood. In addition, the role of $\mathrm{Zn}$ hyperaccumulator plants in $\mathrm{Zn}$ biogeochemical cycling has remained relatively unexplored. However, complementing elemental analysis with stable $\mathrm{Zn}$ isotope ratios can help improve our understanding of $\mathrm{Zn}$ cycling in the rock-soil-plant interface. Organic matter cycling and chemical weathering can lead to $\mathrm{Zn}$ isotope fractionation (Opfergelt et al. 2017; Viers et al. 2015). Zinc isotope signatures in plants is indicative of the main translocation and storage pathways (Moynier et al. 2009; Smolders et al. 2013; Wiggenhauser et al. 2018). Notably, $\mathrm{Zn}$ isotope fractionation between shoot organs varies between plant species (Caldelas and Weiss 2017; Wiggenhauser et al. 2018). In plants from a pristine tropical watershed, preferential translocation of depleted heavy $\mathrm{Zn}$ isotopes into adjacent cells of xylem vessels led to lighter $\mathrm{Zn}$ isotope ratio enrichment in leaves of trees relative to stems (Viers et al. 2007). However, in reed canary grass, light $\mathrm{Zn}$ isotopes preferentially accumulated in stems compared to heavy $\mathrm{Zn}$ isotopes in the leaves (Aucour et al. 2015). Moreover, young leaves were found to have a lighter $\mathrm{Zn}$ isotopic signature compared to mature leaves of reed (Caldelas et al. 2011). Sorption to cell walls, xylem unloading, and storage in vacuoles by binding $\mathrm{Zn}$ to organic acids are suggested for the enrichment of heavy $\mathrm{Zn}$ isotopes in mature leaves relative to stems in reed (Aucour et al. 2015). In wheat, preferential enrichment of light $\mathrm{Zn}$ isotopes accumulate in phloem sinks, whereas phloem sources are enriched in heavy $\mathrm{Zn}$ isotopes, likely because of apoplastic retention and compartmentalization (Wiggenhauser et al. 2018). Noccaea caerulescens, growing on a granite noncontaminated site, preferentially incorporates light $\mathrm{Zn}$ isotopes into the leaves $\left(\delta^{66} \mathrm{Zn}-0.10-0.03 \%\right.$ ) relative $\mathrm{t}$ the o roots ( $\delta^{66} \mathrm{Zn} 0.43-0.49 \%$ ) (Tang et al. 2012). Similarly, A. halleri preferentially incorporates lighter $\mathrm{Zn}$ isotopes in its shoots relative to the roots (Aucour et al. 2015).

Dichapetalum is a large genus comprising more than 150 species primarily occuring in tropical and subtropical regions, with most species known from Africa (Punt 1975). Dichapetalum gelonioides is a woody shrub or small tree which occurs in Southeast Asia. Four subspecies are known to date in Sabah Malaysian Borneo): subsp. gelonioides, subsp. pilosum subsp. sumatranum 
and subsp. tuberculatum. For detailed information on their habitats and main taxonomic characteristics, see Nkrumah et al. (2018). These D. gelonioides subspecies differ in their metal accumulation characteristics: $D$. gelonioides subsp. tuberculatum is a strong nickel $(\mathrm{Ni})$ hyperaccumulator when growing on ultramafic soils, resulting in $>26,000 \mu \mathrm{g} \mathrm{g}^{-1}$ dry mass foliar $\mathrm{Ni}$, and a strong $\mathrm{Zn}$ hyperaccumulator when growing on noncontaminated soils, leading to up to $30,000 \mu \mathrm{g} \mathrm{g}^{-1}$ dry mass foliar Zn (Baker et al. 1992). Dichapetalum gelonioides subsp. sumatranum and D. gelonioides subsp. pilosum are strong $\mathrm{Zn}$ hyperaccumulators on noncontaminated soils, reaching up to $15,700 \mu \mathrm{g} \mathrm{g}^{-1}$ and $26,400 \mu \mathrm{g} \mathrm{g}^{-1}$ dry mass foliar Zn respectively (Baker et al. 1992; Nkrumah et al. 2018). Dichapetalum gelonioides subsp. gelonioides is a non-accumulator. The ability of $D$. gelonioides to hyperaccumulate $\mathrm{Zn}$ from soils with only background concentrations of $\mathrm{Zn}\left(<100 \mu \mathrm{g} \mathrm{g}^{-1}\right)$ is unique, and contrary to other identified $\mathrm{Zn}$ hyperaccumulators, except for the model species A. halleri and $N$. caerulescens. It is also the sole $\mathrm{Zn}$ hyperaccumulator species known to exclusively occur on non- $\mathrm{Zn}$ metalliferous soils, and the only (humid) tropical and woody Zn-hyperaccumulator plant species described so far (van der Ent et al. 2018; Nkrumah et al. 2018).

Hyperaccumulator plants can play a substantial role in the cycling of elements in their local ecosystems, especially in the upper soil horizons, through elemental uptake in the roots, litterfall and litter recycling/ biodegradation (Echevarria 2021; Ratié et al. 2019). In Mediterranean climatic regions, local Ni hyperaccumulator plants directly influence the composition of available and total Ni pools in the ultramafic soils (Estrade et al. 2015). The authors suggested that Ni hyperaccumulators play a major role in maintaining high $\mathrm{Ni}$ concentrations in the surface soils during weathering and pedogenesis. However, to-date, the role of plants in elemental cycling are not yet fully understood (Zelano et al. 2020). Little is known about the $\mathrm{Zn}$ cycling in the parent rock-soil-Zn hyperaccumulator plant interface in tropical regions. This data could provide information about pathways and processes of $\mathrm{Zn}$ that control $\mathrm{Zn}$ recycling in the habitats of tropical $\mathrm{Zn}$ hyperaccumulator plants. Therefore, the primary aim of this study was to use $\mathrm{Zn}$ isotope ratios to investigate $\mathrm{Zn}$ cycling in the parent rock-soil-plant interface in the habitats of the $\mathrm{Zn}$ hyperaccumulators $D$. subsp. pilosum and subsp. sumatranum.

\section{Results}

Zinc concentrations in the Dichapetalum plant tissues, soils and bedrock samples

The $\mathrm{Zn}$ concentrations in the soil and bedrock samples collected from the native habitats of $D$. subsp. pilosum were $<100 \mu \mathrm{g} \mathrm{g}^{-1}$ dry mass (Fig. 1; Table 1 and
Supplementary Table 1). The potentially phytoavailable $\mathrm{Zn}$ concentrations (diethylene triamine pentaacetic acid (DTPA)-extractable $\mathrm{Zn}$ ) were enriched in the topsoil (0$2 \mathrm{~cm}$ ), reaching $30 \mu \mathrm{g} \mathrm{g}^{-1}$ dry mass, whereas that in the rhizosphere soils $\left(0.85-5.5 \mu \mathrm{g} \mathrm{g}^{-1}\right.$ dry mass), the Bhorizon and bedrock $\left(<1 \mu \mathrm{g} \mathrm{g}^{-1}\right.$ dry mass) were relatively depleted. The strontium nitrate $\left(\mathrm{Sr}\left(\mathrm{NO}_{3}\right)_{2}\right)$-extractable $\mathrm{Zn}$ concentrations followed a similar trend, but the rhizosphere soils had higher concentrations relative to the topsoil. The topsoil and the B-horizon of $D$. subsp. pilosum had circum-neutral soil $\mathrm{pH}$, whereas the rhizosphere soils of $D$. subsp. pilosum and $D$. subsp. sumatranum were strongly acidic (Table 1 and Supplementary Table 1).

The $\mathrm{Zn}$ concentrations in the various plant tissues of $D$. subsp. pilosum and $D$. subsp. sumatranum were higher compared to the total and DTPA- and $\mathrm{Sr}\left(\mathrm{NO}_{3}\right)_{2}$ extractable $\mathrm{Zn}$ concentrations in the rhizosphere soils (Table 2). Both $D$. subsp. pilosum and $D$. subsp. sumatranum had similar $\mathrm{Zn}$ accumulation patterns in tissues, but $D$. subsp. sumatranum had relatively higher $\mathrm{Zn}$ concentrations (Table 2). The roots and leaves of $D$. subsp. sumatranum had $\mathrm{Zn}$ concentrations as high as $25,300 \mu \mathrm{g} \mathrm{g}^{-1}$ and $32,400 \mu \mathrm{g} \mathrm{g}^{-1}$, respectively, despite the comparatively lower $\mathrm{Zn}$ concentrations (total and extractable) in the rhizosphere soils $\left(<100 \mathrm{ug} \mathrm{g}^{-1}\right)$ (Figs. 1 and 2). The $\mathrm{Zn}$ concentrations in the senescent leaves, twigs and wood were relatively lower compared to the mature and young leaves, in both Dichapetalum subspecies (Fig. 2). Moreover, the mature leaves had relatively higher $\mathrm{Zn}$ concentrations ( 1.2-fold) compared to the young leaves in both Dichapetalum subspecies. The phloem tissues of both Dichapetalum subspecies had relatively high $\mathrm{Zn}$ concentrations compared to the wood and twigs, reaching $15800 \mu \mathrm{g} \mathrm{g}^{-1}$ in $D$. subsp. sumatranum (Table 2).

Dichapetalum subsp. pilosum and D. subsp. sumatranum had a mean $\mathrm{Zn}$ uptake (root/soil) factor (UF) of 255 and 180, respectively (Fig. 3). Both Dichapetalum subspecies had a mean $\mathrm{Zn}$ translocation (leaves/root) factor $>1.0$. The mean $\mathrm{Zn}$ Bioconcentration Coefficient (BC) (leaf/soil) for $D$. subsp. pilosum and $D$. subsp. sumatranum were 490 and 295, respectively (Fig. 3).

\section{Zinc isotopes in the soil profile and plant tissues}

In the soil profile, the bedrock $\mathrm{Zn}$ was enriched in light $\mathrm{Zn}$ isotopes $\left(\delta^{66} \mathrm{Zn}-0.90 \%\right.$ ) relative to the topsoil $\left(\delta^{66} \mathrm{Zn} 0.13 \%\right.$ ) (Fig. 1). There was a heavy $\mathrm{Zn}$ isotope depletion along the soil profile (Fig. 1). The roots of both 


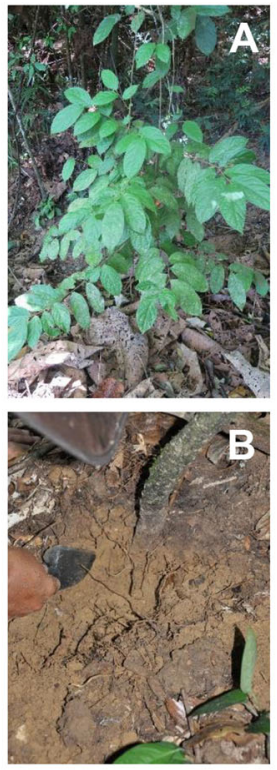

Soil and plant of Dichapetalum gelonioides in the native habitat

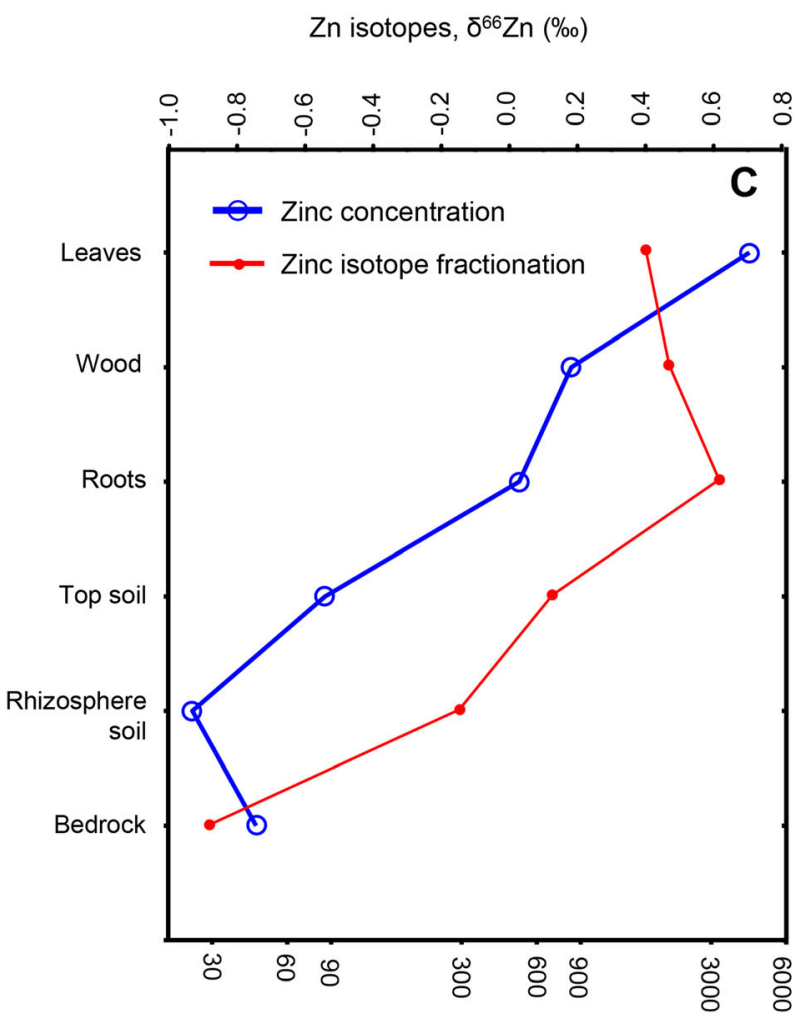

Zinc concentration $\left(\mu \mathrm{g} \mathrm{g}^{-1}\right)$

Fig. 1 (A) Whole plant of Dichapetalum gelonioides subsp. pilosum in the native habitat in Malaysia. (B) Soil profile at the base of this Dichapetalum individual. (C) Mean Zn concentrations $\left(\mu \mathrm{g} \mathrm{g}^{-1}\right)(\mathrm{n}=4)$ (in blue) and $\delta^{66} \mathrm{Zn}$ isotope ratios $(\%)(n=2)$ (in red) of D.subsp. pilosum plant tissues and corresponding topsoil (0-2 cm depth), rhizosphere soil (at 10-30 cm depth) and bedrock (at > $30 \mathrm{~cm}$ depth). The plant tissues include roots, wood and leaves

$D$. subsp. pilosum and $D$. subsp. sumatranum were enriched in heavy $\mathrm{Zn}$ isotopes $\left(\delta^{66} \mathrm{Zn} 0.61-0.66 \%\right.$ ) relative to the mature leaves ( $\delta^{66} \mathrm{Zn} 0.16-0.41 \%$ ) (Table 2). In the aerial parts of $D$. subsp. sumatranum, the mature leaves were preferentially enriched in heavy $\mathrm{Zn}$ isotopes $\left(\delta^{66} \mathrm{Zn} 0.33-0.35 \%\right)$ relative to the young leaves $\left(\delta^{66} \mathrm{Zn}\right.$ $0.25 \%$ ) (Table 2; Fig. 2). The phloem tissue was preferentially enriched in heavy $\mathrm{Zn}$ isotopes $\left(\delta^{66} \mathrm{Zn} 0.72-0.77\right.$ $\%$ ) compared to all plant parts. Moreover, the young leaves $\mathrm{Zn}$ was preferentially enriched in light $\mathrm{Zn}$ isotopes compared to the old twigs and senescent leaves (Table 2). In $D$. subsp. pilosum, $\mathrm{Zn}$ in old twigs were preferentially enriched in heavy $\mathrm{Zn}$ isotopes $\left(\delta^{66} \mathrm{Zn} 0.42 \%\right.$ ) relative to young twigs ( $\delta^{66} \mathrm{Zn} 0.27-0.37 \%$ ).

\section{Discussion}

Our findings reveal that the $\delta^{66} \mathrm{Zn}$ values of the soil profile in the native habitat of Dichapetalum subspecies decrease with soil depth, and the decrease is especially pronounced between the bedrock and soil, suggesting that both chemical weathering and organic matter decomposition in this habitat lead to $\mathrm{Zn}$ fractionation
(Jouvin et al. 2009; Moynier et al. 2017; Opfergelt et al. 2017; Viers et al. 2015). We suggest that the contribution of organic matter to the $\mathrm{Zn}$ fractionation in the soil profile may be more than that of chemical weathering. In Icelandic soils derived from basalt, soil organic matter influences the $\mathrm{Zn}$ fractionation compared to mineral constituents (Opfergelt et al. 2017). In Central Siberia, chemical weathering of basaltic rocks does not lead to chemical and mineralogical differentiation down the soil profiles, resulting in minimal fractionation of $\mathrm{Zn}$ isotopes (Viers et al. 2015). The heavy isotope enrichment in the topsoil relative to deep soil and bedrock may be related to the decay of organic matter induced by microorganisms (Viers et al. 2015; Weiss et al. 2007). Humification processes lead to preferential enrichment of heavy $\mathrm{Zn}$ isotopes as complexation of $\mathrm{Zn}$ by high molecular weight organic compounds (i.e., humic and fulvic acids) favours the enrichment of heavy $\mathrm{Zn}$ isotopes (Jouvin et al. 2009). Our findings indicate that leaf litter recycling strongly influences the soil $\mathrm{Zn}$ budget, leading to Zn-enriched topsoil relative to deep soil and bedrock. In ultramafic ecosystems, vegetation composed of $\mathrm{Ni}$ 
Table. 1 Soil pH, strontium nitrate $\left(\mathrm{Sr}\left(\mathrm{NO}_{3}\right)_{2}\right)$ - and diethylene triamine pentaacetic acid (DTPA)-extractable $\mathrm{Zn}$ concentrations and total Zn concentrations of rhizosphere soils collected from the native habitat of D. subsp. pilosum and D. subsp. sumatranum. The number of samples is 4 for each subspecies; $\mathrm{pH}$ and concentrations are given as ranges and means

\begin{tabular}{lll}
\hline Parameter & Dichapetalum gelonioides subsp. pilosum & Dichapetalum gelonioides subsp. sumatranum \\
\hline $\mathbf{p H}$ & $4.35-4.95$ & $4.80-4.95$ \\
& {$[4.70]$} & {$[4.85]$} \\
$\mathbf{S r}\left(\mathrm{NO}_{\mathbf{3}}\right)_{\mathbf{2}}-\mathbf{Z n}\left(\boldsymbol{\mu \mathbf { g ~ g } ^ { - 1 } )}\right.$ & $0.05-4.0$ & $0.65-6.0$ \\
& {$[1.5]$} & {$[3.0]$} \\
DTPA-Zn $\left(\boldsymbol{\mu} \mathbf{g ~ g}^{-\mathbf{1}}\right)$ & $0.75-5.5$ & $0.75-8.5$ \\
& {$[2.05]$} & {$[4.5]$} \\
Total $\mathbf{Z n}\left(\boldsymbol{\mu} \mathbf{g ~ g}^{-\mathbf{1}}\right)$ & $10-45$ & $55-65$ \\
& {$[25]$} & {$[60]$} \\
\hline
\end{tabular}

hyperaccumulators can significantly influence $\mathrm{Ni}$ isotopic compositions (with enrichment in lighter $\mathrm{Ni}$ isotopes) through its remobilization in the upper soil horizons (Estrade et al. 2015; Paul et al. 2021; Zelano et al. 2020).

With regards to root-to-shoot translocation, our findings are consistent with previous studies showing preferential incorporation of light $\mathrm{Zn}$ isotopes in mature leaves relative to roots (Caldelas et al. 2011; Deng et al. 2014; Jouvin et al. 2012; Moynier et al. 2009; Tang et al. 2012, 2016; Viers et al. 2007; Wiggenhauser et al. 2018). In plant roots, there is preferential enrichment of heavy $\mathrm{Zn}$ isotopes in $\mathrm{Zn}$ retained by O-ligands of pectincontaining cell walls, particularly the $\mathrm{Zn}$ fraction that is tightly bound to such cell walls (Aucour et al. 2015; Tang et al. 2016). Hence, there is a preferential transfer of light $\mathrm{Zn}$ isotopes from roots to mature leaves through the xylem. Notably, $\mathrm{O}$ and $\mathrm{N}$ donor ligands preferentially bind heavy $\mathrm{Zn}$ isotopes (Fujii et al. 2014), which leads to an enrichment of light $\mathrm{Zn}$ isotopes in the cytosolic $\mathrm{Zn}^{2+}$ pool. Therefore, membrane transport likely favours light $\mathrm{Zn}$ isotopes (Caldelas and Weiss 2017). In the Zn hyperaccumulator $N$. caerulescens, the upregulation of heavy metal ATPases (HMAs) drives efficient root-shoot $\mathrm{Zn}$ translocation (Merlot et al. 2021; Papoyan and Kochian 2004; Schvartzman et al. 2018; Verbruggen et al. 2009), which likely leads to preferential transfer of light $\mathrm{Zn}$ isotopes to the xylem (Tang et al. 2012). Our results suggest that $\mathrm{Zn}$ transporters, like HMAs, may be highly expressed in the roots of Zn-hyperaccumulating subspecies of D. gelonioides, as observed in $N$. caerulescens (Tang et al. 2012; Merlot et al. 2021).

Zinc from mature leaves is redistributed via the phloem to young plant organs (Page and Feller 2015). The $\mathrm{Zn}$ concentrations in the young leaves of the Dichapetalum subspecies here are relatively high in comparison with other aerial parts. This implies that $\mathrm{Zn}$ redistribution by the phloem in Dichapetalum is highly effective, with both senescent and mature leaves supplying $\mathrm{Zn}$ to the young leaves via phloem redistribution. Zinc derived from the xylem (if the leaves are transpiring) replaces $\mathrm{Zn}$ released from the mature leaves, whereas the $\mathrm{Zn}$ from the senescent leaves is not replaced, leading to $\mathrm{Zn}$ depletion (Table 2). The $\mathrm{Zn}$ isotope ratios in the senescent and mature leaves compared to the young leaves suggest that light isotopes are preferably remobilized from the phloem sources. This is consistent with $\mathrm{Zn}$ transfer at flowering and full maturity in wheat

Table. 2 Zinc concentrations $\left(\mu \mathrm{g} \mathrm{g}^{-1}\right)(n=4)$ and $\delta^{66} \mathrm{Zn}$ isotopic ratios $(\%)(n=2)$ for field collected plant samples from the native habitat of D. subsp. pilosum and D. subsp. sumatranum. Concentrations are given in ranges and mean, and isotope ratios are given in ranges

\begin{tabular}{|c|c|c|c|c|c|c|}
\hline \multirow[t]{2}{*}{ Plant Fraction } & \multicolumn{3}{|c|}{ Dichapetalum gelonioides subsp. pilosum } & \multicolumn{3}{|c|}{ Dichapetalum gelonioides subsp. sumatranum } \\
\hline & Zinc concentrations $\left(\mu \mathrm{g} \mathrm{g}^{-1}\right)$ & $\delta^{66} \mathrm{Zn}$ isotopic ratios (\%o) & SD & Zinc concentrations $\left(\mu \mathrm{g} \mathrm{g}^{-1}\right)$ & $\delta^{66} \mathrm{Zn}$ isotopic ratios (\%o) & SD \\
\hline Young Leaves & $3750-11100[6970]$ & $0.26-0.41$ & $0.04-0.05$ & $4250-32400$ [14 400] & 0.24 & $0.06-0.08$ \\
\hline Old Leaves & $6370-11200[8350]$ & $0.16-0.41$ & $0.05-0.08$ & 5370-30 800 [17 400] & $0.33-0.35$ & $0.04-0.07$ \\
\hline Senescent Leaves & $3740-9850$ [6400] & $0.26-0.39$ & $0.04-0.07$ & - & - & - \\
\hline Phloem tissue & $3100-4050$ [3580] & $0.23-0.50$ & 0.05 & $3420-15800$ [9610] & $0.72-0.77$ & $0.05-0.06$ \\
\hline Young twigs & $1910-5450$ [4320] & $0.27-0.37$ & 0.06 & 250-13400 [5620] & $0.36-0.37$ & 0.05 \\
\hline Old twigs & 680-1850 [1330] & 0.42 & $0.05-0.07$ & 2250-7610 [4070] & 0.7 & 0.07 \\
\hline Wood & $640-2180$ [1180] & $0.18-0.48$ & $0.03-0.06$ & $780-13700$ [5550] & $0.37-0.64$ & 0.05 \\
\hline Main roots & $2900-5470$ [4010] & $0.63-0.66$ & $0.05-0.06$ & $1860-25300\left[\begin{array}{ll}11 & 200\end{array}\right]$ & $0.61-0.62$ & $0.04-0.05$ \\
\hline
\end{tabular}




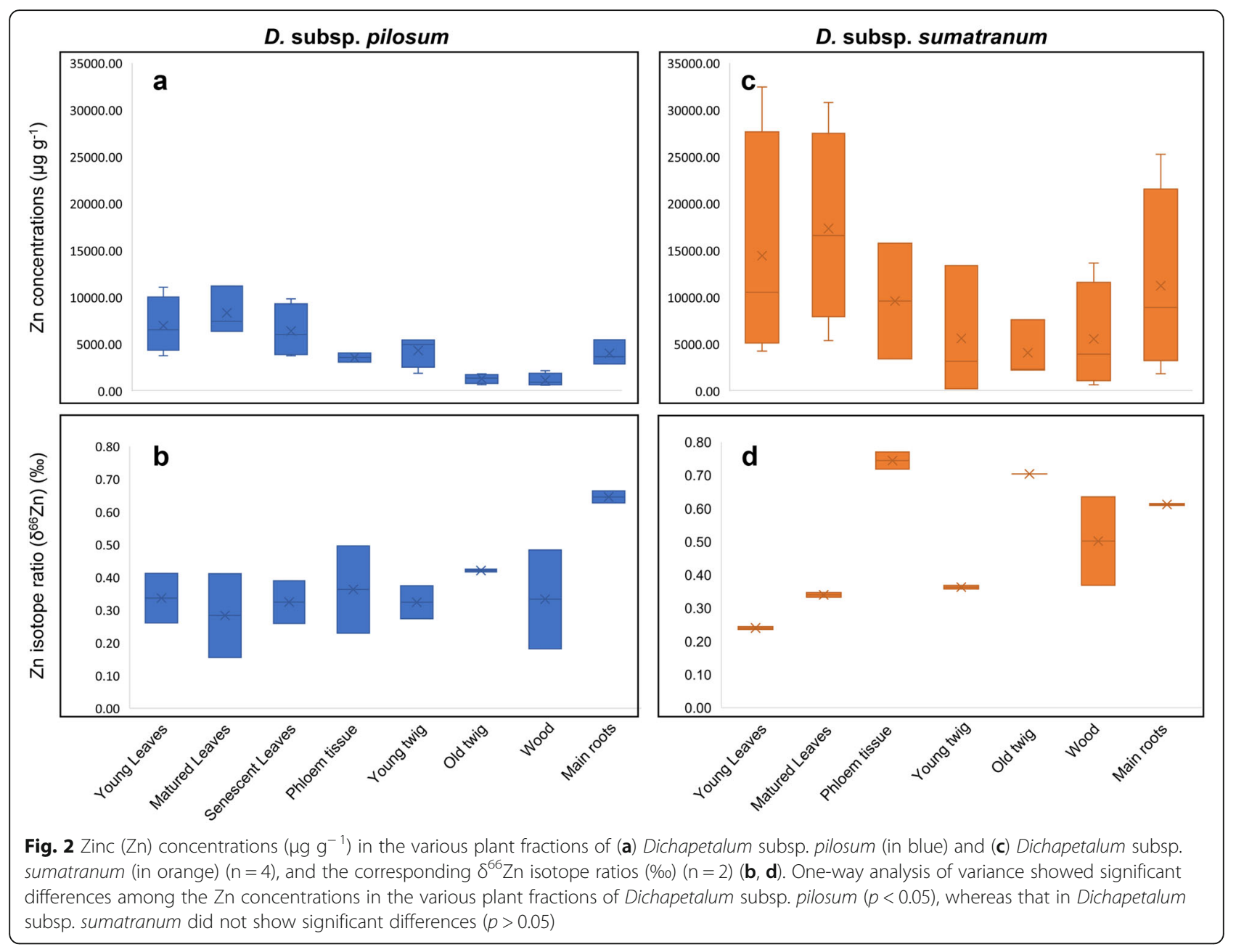

where phloem sources (e.g., senescent straw) are preferentially enriched in heavy $\mathrm{Zn}$ isotopes, whereas phloem sinks (e.g., young leaves and grains) are enriched in light $\mathrm{Zn}$ isotopes (Wiggenhauser et al. 2018). Notably, the phloem tissues of $D$. subsp. sumatranum have the greatest heavy $\mathrm{Zn}$ isotopes enrichment $\left(\delta^{66} \mathrm{Zn} 0.72-0.77 \%\right.$ ), whereas young leaves have the smallest $\left(\delta^{66} \mathrm{Zn}=0.24 \%\right.$ o of the tissues examined. This finding suggests that $\mathrm{Zn}$ absorption to cell walls in the apoplastic space preferentially retains heavy isotopes in phloem sources (Aucour et al. 2015, 2017; Tang et al. 2016; Wiggenhauser et al. 2018). Moreover, these authors suggest $\mathrm{Zn}$ complexation and compartmentalization in cells contribute to the enrichment of light $\mathrm{Zn}$ isotopes in phloem sinks. Isotopically heavy $\mathrm{Zn}$ is preferentially sorbed to the cell walls of diatoms (John et al. 2007). The large enrichment of heavy $\mathrm{Zn}$ in the phloem tissue (a major phloem source) relative to the young leaves (phloem sink) of $D$. subsp. sumatranum also suggests that transporters and chelators within the phloem sap (Clemens 2019) preferentially complex/bind heavy $\mathrm{Zn}$ isotopes (Fujii et al. 2014).

\section{Conclusions}

The findings from this study suggest that both weathering and $\mathrm{Zn}$-enriched organic matter recycling influence the enrichment of heavy $\mathrm{Zn}$ isotopes in the topsoil relative to deep soil and parent rock, with the latter likely being the dominant factor. Zinc isotopic fractionation occurs within the plants, with root-to-shoot translocation favouring light isotope enrichment in wood and mature leaves relative to roots. In the aerial parts of this Dichapetalum, $\mathrm{Zn}$ redistribution via the phloem leads to heavy $\mathrm{Zn}$ isotope enrichment in phloem sources relative to phloem sinks, likely due to apoplastic retention and compartmentalization. Taken together, this study reveals the substantial role that Dichapetalum subspecies play in the $\mathrm{Zn}$ biogeochemical cycling of the local ecosystem.

\section{Methods}

Study locations and habitat of Dichapetalum gelonioides

We collected the soil and plant samples in the rainforest habitat in Malaysian Borneo at the Sepilok-Kabili Forest Reserve for D. gelonioides subsp. sumatranum and at 


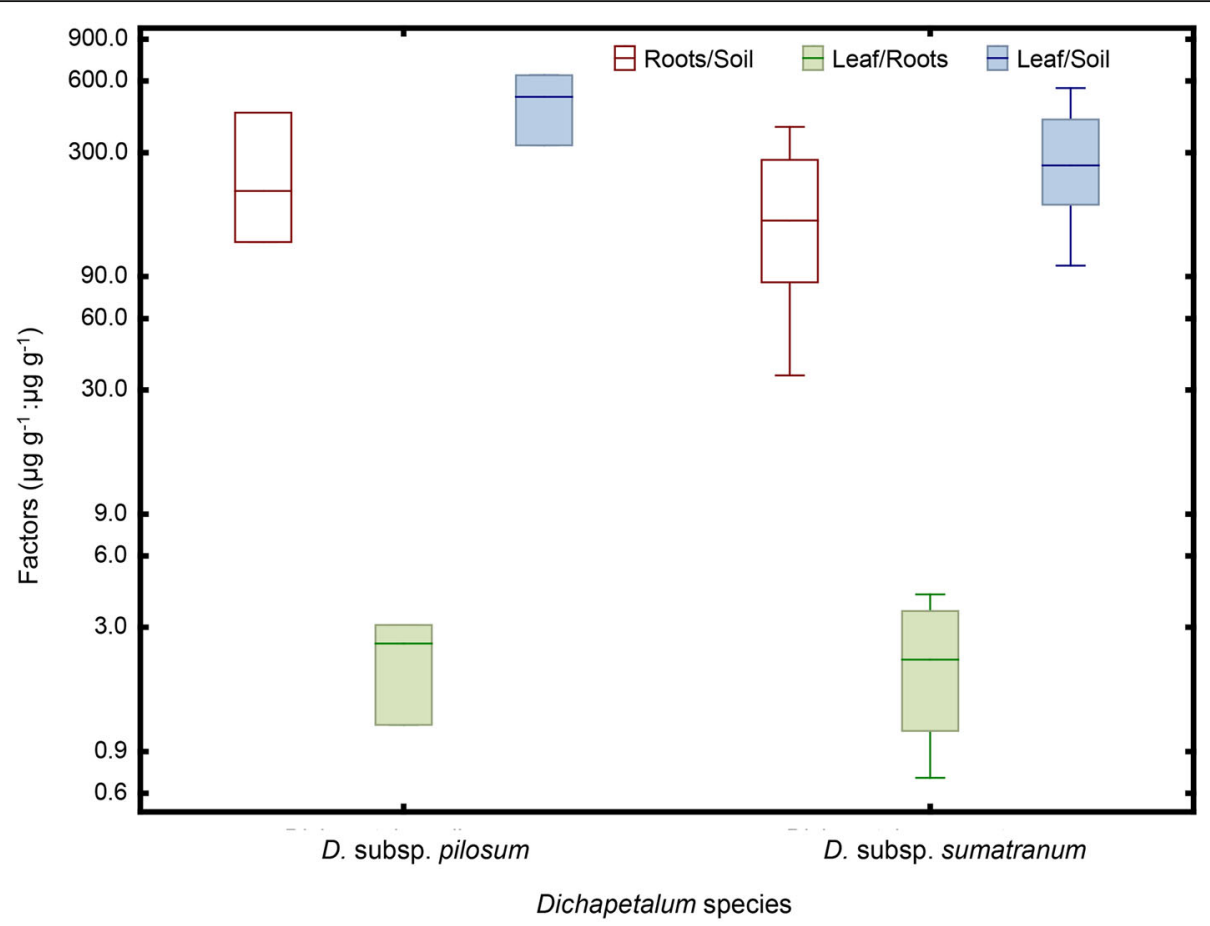

Fig. 3 Zinc uptake (roots/soil) (in white), translocation (leaf/root) (in green) and bioaccumulation (leaf/soil) (in blue) factors of field collected Dichapetalum gelonioides subsp. pilosum and Dichapetalum gelonioides subsp. sumatranum. These factors are given in $\mu \mathrm{g} \mathrm{g}^{-1}: \mu \mathrm{g} \mathrm{g}^{-1}$. Key to symbols of boxplots: whiskers are \pm standard deviation (SD)

the Kebun China Forest Reserve for D. gelonioides subsp. pilosum (Fig. 4). The Sabah Forest Department granted access to the Sepilok-Kabili and the Kebun China Forest Reserves and the Sabah Biodiversity Council granted research permits. Species will further be annotated in the manuscript as $D$. subsp. sumatranum and D. subsp. pilosum, respectively. The SepilokKabili Forest Reserve is approximately 5529 ha. The geology of the area is mudstone, sandstone and some siltstone of the Upper Miocene. The primary rain forest is dominated by Parashorea malaanonan-Eusideroxylon zwageri, Shorea multiflora, Dipterocarpus acutangulus and Shorea beccariana. This hill forest on sandstone-derived soils has a 34-40 m tall canopy. The Kebun China Forest Reserve is 149 ha and its geology also comprise of mudstone and sandstone, but this secondary forest is degraded (it has been previously logged and is partly burned).

Collection of $D$. subsp. sumatranum and $D$. subsp. pilosum plant tissues

We collected plant tissue samples (roots, wood, old twigs, young twigs, mature (fully expanded) leaves, senescent leaves, young leaves and phloem tissue) from four individual plants of $D$. subsp. sumatranum and $D$. subsp. pilosum in the habitat following methods described by van der Ent and Mulligan (2015). The plant tissues were thoroughly rinsed with distilled water to remove surface contamination as much as possible, and then oven-dried at $70{ }^{\circ} \mathrm{C}$ for 5 days. All samples were packed for transport to Australia and gamma irradiated at Steritech Pty. Ltd. in Brisbane following Australian quarantine regulations. The plant samples were again ovendried at $70{ }^{\circ} \mathrm{C}$ for five days to a constant mass. Each sample was ground to a fine powder, weighed and a 300 mg quantity digested using $7 \mathrm{~mL}$ concentrated nitric acid $\left(\mathrm{HNO}_{3}\right)$ in an open vessel microwave oven (Milestone Start D) for $45 \mathrm{~min}$ at $125^{\circ} \mathrm{C}(\sim 250 \mathrm{~W})$. Following digestion, the samples were cooled and brought to volume $(40 \mathrm{~mL})$ with ultrapure deionised water.

\section{Collection of field rhizosphere soil and bedrock samples atD.subsp.sumatranumandD.subsp.pilosumfield sites}

We collected rhizosphere soil samples from the four individual plants of $D$. subsp. sumatranum and $D$. subsp. pilosum. In addition, we collected soil at varying depths (0-2 cm (O), 2-10 cm (A)) and bedrock samples (at > $30 \mathrm{~cm}$ depth) from near the roots of D. subsp. pilosum. These soils and bedrock samples were packed for transport to Australia and gamma irradiated at Steritech Pty. Ltd. in Brisbane as required by Australian quarantine regulations. The soil was air dried and sieved to $<2-\mathrm{mm}$ before grinding into a fine powder using a ball 

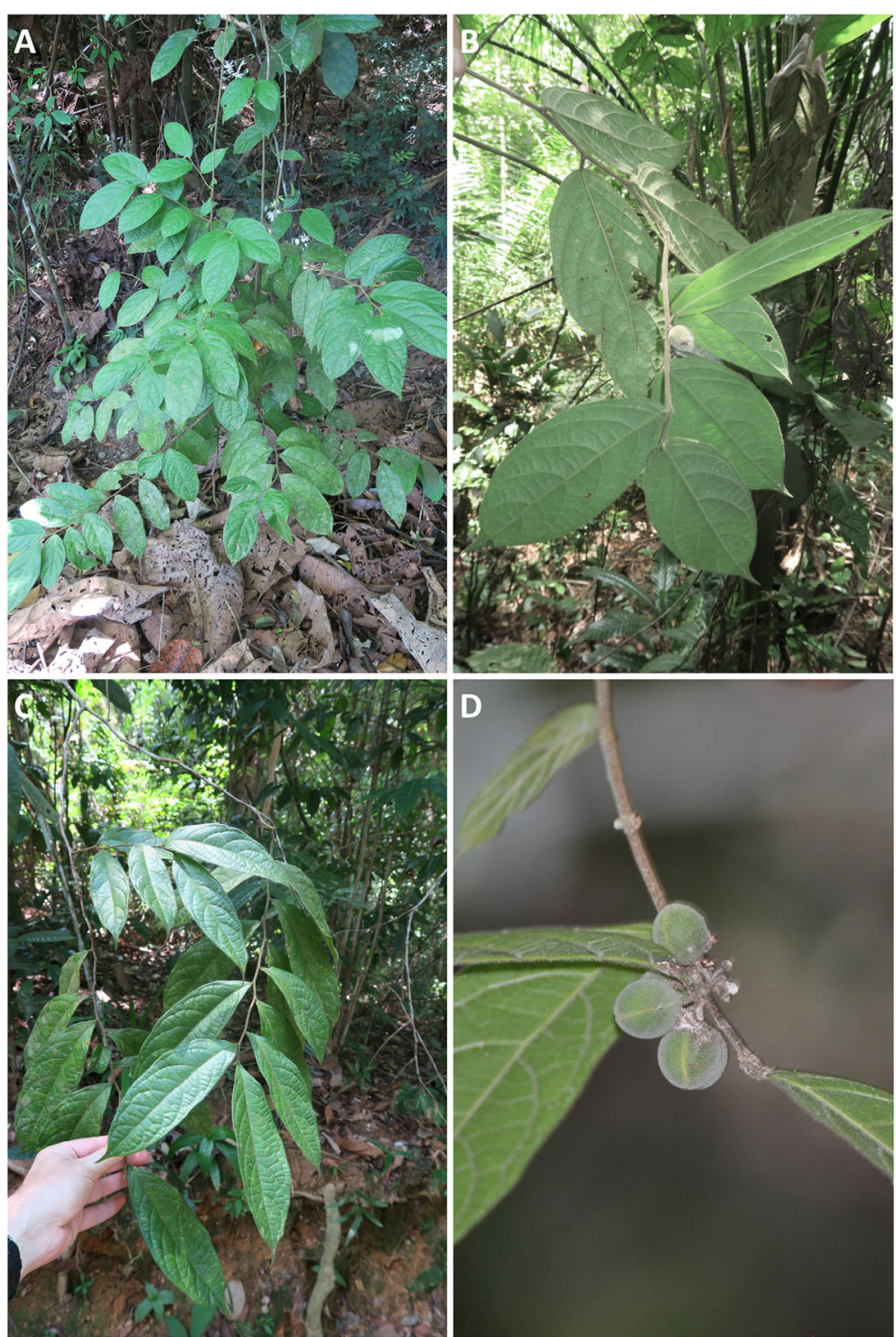

Fig. 4 (A) Whole plant and (C) branch of Dichapetalum gelonioides subsp. sumatranum, and (B, D) branches of D. gelonioides subsp. pilosum with fruits in their native habitats in the Malaysian Borneo. Around the plants (A) there is substantial leaf litter on the topsoil

mill (Retsch PM200). Similarly, the bedrock samples were crushed and ground into a fine powder. Soil and bedrock sub-samples $(\sim 300 \mathrm{mg})$ were strong acid leached/extracted using $9 \mathrm{~mL}$ concentrated $\mathrm{HNO}_{3}$ and 3 $\mathrm{mL}$ concentrated hydrochloric acid $(\mathrm{HCl})$ in an open vessel microwave oven (Milestone Start D) for $1.5 \mathrm{~h}$ at $125^{\circ} \mathrm{C}(\sim 250 \mathrm{~W})$. Following digestion, samples were brought to volume $(40 \mathrm{~mL})$ with ultrapure deionised water. Soil $\mathrm{pH}$ was determined in a 1:2.5 soil:water $(\mathrm{m} / \mathrm{v})$ mixture after $2 \mathrm{~h}$ shaking and $1 \mathrm{~h}$ rest. Exchangeable trace elements were extracted in $0.01 \mathrm{M}$ strontium nitrate $\left(\mathrm{Sr}\left(\mathrm{NO}_{3}\right)_{2}\right)$ at a soil: solution ratio of $1: 4(\mathrm{~m} / \mathrm{v})(10 \mathrm{~g}$ soil with $40 \mathrm{~mL}$ solution) and $2 \mathrm{~h}$ shaking time (adapted from Kukier and Chaney 2001). A diethylene triamine pentaacetic acid (DTPA)-extractant was used to determine the potentially phytoavailable trace concentrations in soils following the method of Becquer et al. (1995), which was adapted from the original method by Lindsay and Norvell (1978), with the following modifications: excluding triethanolamine (TEA), adjusted to $\mathrm{pH} 5.3,5 \mathrm{~g}$ soil with $25 \mathrm{~mL}$ extractant, and extraction time of $1 \mathrm{~h}$.

\section{Total $\mathrm{Zn}$ analysis of soils, bedrock and plant tissues}

The plant digests and soils and bedrock digests/extracts were analysed by inductively coupled plasma atomic emission spectroscopy (ICP-AES; Thermo Scientific iCAP 7400) for $\mathrm{Zn}$ concentrations. In-line internal addition standardization using yttrium was 
used to correct for matrix-based interferences. Quality controls included matrix blanks, Standard Reference Material (NIST 1570a Spinach Leaves digested with $\left.\mathrm{HNO}_{3}\right)$. The measured values $\mathrm{Zn}$ concentra-

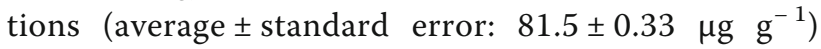
were in close agreement with the certified value of $82.3 \mu \mathrm{g} \mathrm{g}^{-1}$.

\section{Estimation of the uptake, translocation and bioconcentration coefficient factors}

The $\mathrm{Zn}$ uptake (root/soil) factor (UF) is the ratio of $\mathrm{Zn}$ concentrations in roots to that of the rhizosphere soil. The $\mathrm{Zn}$ translocation (leaves/root) factor is given as the ratio of $\mathrm{Zn}$ concentrations in leaves to that of the roots. The $\mathrm{Zn}$ Bioconcentration Coefficient (BC) (leaf/soil) is the ratio of $\mathrm{Zn}$ concentrations in leaves to that of the rhizosphere soils.

\section{Zinc isotope ratio analysis}

Plant tissue samples $(n=2)$ for $D$. subsp. sumatranum and $D$. subsp. pilosum were digested using a protocol based on US EPA method 3502 (US Environmental Protection Agency 1996). Approximately $0.2 \mathrm{~g}$ of homogenized powder was weighed into a $15-\mathrm{mL}$ perfluroalkoxy (PFA) vial, then $8 \mathrm{~mL}$ concentrated $\mathrm{HNO}_{3}$ was added. The sample was cold digested overnight, followed by the addition of $1 \mathrm{~mL}$ hydrogen peroxide $\left(\mathrm{H}_{2} \mathrm{O}_{2}\right)$. The solution was monitored for effervescence/spillage then a second addition of $1 \mathrm{~mL} \mathrm{H}_{2} \mathrm{O}_{2}$ was performed. The resulting $10 \mathrm{~mL}$ solution was decanted into Teflon vessels for closed vessel microwave digestion at $180{ }^{\circ} \mathrm{C}$ for $30 \mathrm{~min}$ (Anton-Parr; $1000 \mathrm{~W}$ ). After digestion, the solution was transferred to clean 15-mL PFA vials and subsampled for total $\mathrm{Zn}$ analysis by inductively coupled plasma - mass spectrometry (ICP-MS) (Agilent 8900) and column purification (resin anion-exchange chromatography) prior to multi-collector inductively coupled plasma-mass spectrometry (MC-ICP-MS) analysis. The accuracy of digestion and analysis methods for determination of $\mathrm{Zn}$ concentrations was monitored by analysing Certified Reference Materials ('CRM') 1567b (wheat flour) and 1573a (tomato leaves). The $\mathrm{Zn}$ concentrations found in CRMs samples were in close agreement with the certified values.

Total $\mathrm{Zn}$ concentrations in soil and bedrock samples $(\mathrm{n}=2)$ from different depths in the profile $(\mathrm{O}, \mathrm{A}, \mathrm{B}$ and $\mathrm{R})$ were determined by weighing between 0.2 and $0.3 \mathrm{~g}$ dry mass into a $15-\mathrm{mL}$ perfluoroalkyl (PFA) vial. The sample was digested for 4 days at $120^{\circ} \mathrm{C}$ on a hot plate in a mixture of concentrated $\mathrm{HNO}_{3}$ and concentrated hydrofluoric (HF) acids. The samples were evaporated to dryness, during which $\mathrm{HNO}_{3}$ was added to drive off the HF. The samples were digested for a further 4 days in $\mathrm{HNO}_{3} / \mathrm{H}_{2} \mathrm{O}_{2}$ mixture. After digestion, the samples were separated into two aliquots for total $\mathrm{Zn}$ concentrations using ICP-AES or ICP-MS and column purification (ion exchange chromatography) prior to MC-ICP-MS analysis of $\mathrm{Zn}$ isotope ratios. The accuracy of digestion and analysis methods for determination of $\mathrm{Zn}$ concentrations was monitored by analysing CRM 2709a (San Joaquin soil). The $\mathrm{Zn}$ concentrations found in the CRM were in close agreement with the certified value.

Zinc was separated from other matric elements (including copper $(\mathrm{Cu}), \mathrm{Ni}$, iron $(\mathrm{Fe})$ ) using a modified column purification procedure outlined by Sossi et al. (2014). Briefly, aliquots of plant or soil digest solutions (1000-1200 ng Zn) were evaporated in PFA vials to dryness at $80{ }^{\circ} \mathrm{C}$. The samples were converted to the chloride form by adding $2 \mathrm{~mL}$ of $6 \mathrm{M} \mathrm{HCl}$ and evaporating to dryness. The samples were taken up in $1 \mathrm{~mL}$ of $6 \mathrm{M}$ $\mathrm{HCl}$ for loading into Poly-Prep ${ }^{\mathrm{Tw}}$ columns loaded with 2 $\mathrm{mL}$ of AG1-X8 100-200 mesh ion-exchange resin. The column cleaning and elution procedures are summarized in Supplementary Table 2. $6 \mathrm{M} \mathrm{HCl}$ was used to elute major elements such as aluminium $(\mathrm{Al})$, sodium $(\mathrm{Na})$, calcium (Ca) and doubly charged elements (titanium (Ti) and barium (Ba)) from the column. Transition metals such as $\mathrm{Cu}$ and $\mathrm{Fe}$ were then eluted with $0.5 \mathrm{M}$ $\mathrm{HCl}$, and $\mathrm{Zn}$ fraction was then eluted with $15 \mathrm{~mL}$ of $0.5 \mathrm{M} \mathrm{HNO}_{3}$. The collected $\mathrm{Zn}$ fraction was evaporated to dryness at $90{ }^{\circ} \mathrm{C}$ and taken up in $3 \mathrm{~mL}$ of $2 \% \mathrm{v} / \mathrm{v}$ $\mathrm{HNO}_{3}$ for MC-ICP-MS analysis. An aliquot of $1 \mathrm{~mL}$ was sub-sampled to measure total $\mathrm{Zn}$ concentrations and range of matrix elements (e.g. $\mathrm{Cu}, \mathrm{Ni}, \mathrm{Fe}, \mathrm{Ca}, \mathrm{Na}$, potassium (K), Ti) by ICP-MS (Agilent 8900 ) to check Zn recovery and that matrix and interfering elements had been removed from the $\mathrm{Zn}$ fraction. Recoveries of $\mathrm{Zn}$ from sample columns were between 96 and $136 \%$.

Zinc isotope ratios were determined using MC-ICPMS (Neptune, Thermo Scientific) housed at Waite Campus, Adelaide, Australia. The samples were measured in $2 \% \mathrm{HNO}_{3}$ at $\mathrm{Zn}$ concentrations between 350 and $400 \mu \mathrm{g} \mathrm{L}^{-1}$. Samples were measured in low resolution mode, using $\mathrm{H}$ cones and a $50 \mu \mathrm{L} \min ^{-1}$ nebulizer attached to a Scott double pass quartz spray chamber. Masses ${ }^{62} \mathrm{Ni},{ }^{63} \mathrm{Cu},{ }^{64} \mathrm{Zn},{ }^{65} \mathrm{Cu},{ }^{66} \mathrm{Zn},{ }^{67} \mathrm{Zn}$ and ${ }^{68} \mathrm{Zn}$ were measured simultaneously, with ${ }^{62} \mathrm{Ni}$ monitored to correct for ${ }^{64} \mathrm{Ni}$ interference on ${ }^{64} \mathrm{Zn}$ (no interference on ${ }^{64} \mathrm{Zn}$ due to ${ }^{64} \mathrm{Ni}$ was observed in this study). A single run consisted of 1 block of 35 cycles with $4 \mathrm{~s}$ integration time. A baseline and peak centre were performed before each run. The standard-sample-standard bracketing method was used using $\mathrm{Zn}$ isotopic standard IRMM 3702 as the bracketing standard. Samples were spiked with $400 \mu \mathrm{g} \mathrm{L}^{-1} \mathrm{Cu}$ for instrumental mass bias correction by external normalization using the exponential law (Marechal et al. 1999). An in-house isotopic $\mathrm{Cu}$ standard ('STD1') with a copper isotope ratio, ${ }^{65} \mathrm{Cu} /{ }^{63} \mathrm{Cu}=0.45$ 
(similar to that of NIST $976=0.45$ ) was used for instrumental mass bias correction. An on-peak zero correction was performed by measuring a blank before and after each sample and bracketing standard. The $\mathrm{Zn}$ isotope results are reported in 'per mil' notation with $\delta^{66} \mathrm{Zn}$ defined as:

$$
\begin{aligned}
& \delta^{66} \mathrm{Zn} \\
& 1000
\end{aligned}
$$

Zinc isotopes have previously been reported in the literature relative to the JMC-Lyon reference value. The conversion factor between the two standards can be determined using the following formulae (Sossi et al. 2014):

$$
\delta^{66} \mathrm{Zn}_{3702}=\delta^{66} \mathrm{Zn}_{\text {JMC }}+0.30
$$

The analytical blank (digestion and column) represented $<3 \%$ of the total $\mathrm{Zn}$ concentration in samples for MC-ICP-MS analysis. The accuracy of digestion, purification and analysis procedures for the determination of $\delta^{66} \mathrm{Zn}$ in plant tissues, soils and bedrock samples was assessed using the CRM's NIST1567b (wheat flour) and NIST1573a (tomato leaves); and CRM NIST2709a (San Joaquin soil). The measured values (average $\pm 2 \mathrm{SD}$; CRM 1567b $\delta^{66} \mathrm{Zn}=0.98 \pm 0.04 ;$ CRM $1573 \mathrm{a} \delta^{66} \mathrm{Zn}=$ $0.45 \pm 0.06$; CRM 2709a $\left.\delta^{66} \mathrm{Zn}=-0.02 \pm 0.06\right)$ were in close agreement with published values (CRM 1567b $\delta^{66} \mathrm{Zn}=0.95 \pm 0.05 ; \mathrm{CRM} 1573 \mathrm{a} \delta^{66} \mathrm{Zn}=0.49 \pm 0.09$; CRM 2709a $\delta^{66} \mathrm{Zn}=-0.02$ ) (Araujo et al. 2017; Wiggenhauser et al. 2018).

\section{Abbreviations \\ BC: Bioconcentration Coefficient; CRM: Certified Reference Materials; DTPA: Diethylene triamine pentaacetic acid; HMAs: Heavy metal ATPases; ICP-AES: Inductively-coupled plasma - atomic emission spectroscopy; ICP- MS: Inductively-coupled plasma-mass spectrometry; IRMM: Institute for Reference Materials and Measurements; JMC: Johnson Matthey Company; m/ v: Mass-volume ratio; MC-ICP-MS: Multi-collector inductively coupled plasma- mass spectrometry; n: Number of samples; NIST: National Institute of Standards and Technology; PFA: Perfluroalkoxy; SD: Standard deviation; STD1: In-house isotopic copper standard; TEA: Triethanolamine; UF: Uptake factor; v/v: Volume-volume ratio; $\delta^{66} \mathrm{Zn}$ : Zinc isotope ratio}

\section{Supplementary Information}

The online version contains supplementary material available at https://doi. org/10.1186/s12870-021-03190-4.

\section{Additional file 1: Supplementary Table S1. Soil pH, strontium nitrate-} and diethylene triamine pentaacetic acid (DTPA)-extractable $\mathrm{Zn}$ concentrations $\left(\mu \mathrm{g} \mathrm{g}^{-1}\right)$, total $\mathrm{Zn}$ concentrations and $\delta^{66} \mathrm{Zn}$ isotope ratios $(\%)$ of soil profile $(0-2 \mathrm{~cm}(\mathrm{O})$, Soil $2-10 \mathrm{~cm}(\mathrm{~A}))$ and bedrock $(30 \mathrm{~cm}(\mathrm{R}))$ samples collected from the native habitat of Dichapetalum gelonioides subsp. pilosum. SD = standard deviation (instrumental analysis variability). Supplementary Table S2. Procedure for separating and purifying $\mathrm{Zn}$ for isotope measurements by multi-collector inductively coupled plasma-mass spectrometry (MC-ICP-MS).

\section{Acknowledgements}

We thank the Sabah Forest Department for granting access to the SepilokKabili and Kebun China Forest Reserves and acknowledge Sabah Biodiversity Council for granting research permits. We thank John Sugau for his support for the research, and Sukaibin Sumail and Postar Miun and Jemson Miun for assistance in the field. The French National Research Agency through the national "Investissements d'avenir" program (ANR-10-LABX-21, LABEX

RESSOURCES21) is acknowledged for funding support to A. van der Ent and P. N. Nkrumah. The latter author was the recipient of an Australian Government Research Training Program Scholarship and UQ Centennial Scholarship at The University of Queensland, Australia. A. van der Ent was the recipient of a Discovery Early Career Researcher Award (DE160100429) from the Australian Research Council.

\section{Authors' contributions}

A.v.d.E., P.N.N., M.G.M.A. and A.J.M.B. collected and processed samples for experiments. F.D., C.W. and J.K.B. conducted stable isotope experiments. All authors contributed to writing of the manuscript. The authors read and approved the final manuscript.

\section{Funding}

The French National Research Agency through the national "Investissements d'avenir" program (ANR-10-LABX-21, LABEX RESSOURCES21) is acknowledged for funding support to A. van der Ent and P. N. Nkrumah. The latter author was the recipient of an Australian Government Research Training Program Scholarship and UQ Centennial Scholarship at The University of Queensland, Australia. A. van der Ent was the recipient of a Discovery Early Career Researcher Award (DE160100429) from the Australian Research Council.

\section{Availability of data and materials}

The datasets used and/or analysed during the current study are available from the corresponding author on reasonable request.

\section{Declarations}

Ethics approval and consent to participate

Not applicable.

\section{Consent for publication}

Not applicable.

\section{Competing interests}

The authors declare that they have no competing interests.

\section{Author details}

${ }^{1}$ Centre for Mined Land Rehabilitation, Sustainable Minerals Institute, The University of Queensland, Queensland 4072 St Lucia, Australia. ${ }^{2}$ Laboratoire Sols et Environnement, Université de Lorraine-INRAE, UMR 1120, Nancy, France. ${ }^{3}$ Laboratory of Genetics, Wageningen University and Research, Wageningen, The Netherlands. 'School of BioSciences, The University of Melbourne, Victoria, Melbourne, Australia. ${ }^{5}$ Soil Sciences, University of Adelaide, South Australia, Adelaide, Australia. ${ }^{6}$ Industry Environments Program, CSIRO Land and Water, Environmental Assessment and Technologies, Adelaide, South Australia, Australia.

Received: 12 March 2021 Accepted: 2 July 2021

Published online: 27 September 2021

\section{References}

Ajeesh Krishna T.P., Ceasar S.A., Maharajan T., Ramakrishnan M., Duraipandiyan V., Al-Dhabi N.A., Ignacimuthu S. (2017). Improving the zinc-use efficiency in plants: A Review. SABRAO Journal of Breeding and Genetics 49:211-230.

Andresen E., Peiter E., Küpper H. (2018). Trace metal metabolism in plants. Journal of Experimental Botany 69:909-954.

Araujo D., Boaventura G., Viers J., Mulholland D., Weiss D., Araujo D., Lima B., Ruiz I., Machado W., Babinski M., Dantas E. (2017). Ion exchange chromatography and mass bias correction for accurate and precise $\mathrm{Zn}$ isotope ratio measurements in environmental reference materials by MC-ICP-MS. Journal of the Brazilian Chemical Society 28:225-235.

Assunção A., Martins P.D.C., De Folter S., et al. (2001). Elevated expression of metal transporter genes in three accessions of the metal hyperaccumulator Thlaspi caerulescens. Plant, Cell \& Environment 24: 217-226.

Assunção A.G., Bleeker P., Wilma M., et al. (2008). Intraspecific variation of metal preference patterns for hyperaccumulation in Thlaspi caerulescens: evidence from binary metal exposures. Plant and Soil 303: 289-299. 
Assunção A.G., Bookum W.M., Nelissen H.J., et al. (2003). Differential metal-specific tolerance and accumulation patterns among Thlaspi caerulescens populations originating from different soil types. New Phytologist 159: 411-419.

Aucour A.-M., Pichat S., Macnair M.R., Oger P. (2011). Fractionation of stable zinc isotopes in the zinc hyperaccumulator Arabidopsis halleri and nonaccumulator Arabidopsis petraea. Environmental Science and Technology 45: 9212-9217.

Aucour A.-M., Bedell J.-P., Queyron M., Magnin V., Testemale D., Sarret G. (2015). Dynamics of $\mathrm{Zn}$ in an urban wetland soil-plant system: Coupling isotopic and EXAFS approaches. Geochimica et Cosmochimica Acta 160: 55-69.

Aucour A.-M., Bedell J.-P., Queyron M., Tholé R., Lamboux A., Sarret, G. (2017). Zn speciation and stable isotope fractionation in a contaminated urban wetland soil-Typha latifolia system. Environmental Science and Technology 51: 8350 8358.

Baker A.J.M. (1981). Accumulators and excluders-strategies in the response of plants to heavy metals. Journal of Plant Nutrition 3: 643-654.

Baker A.J.M., Brooks R.R. (1989). Terrestrial higher plants which hyperaccumulate metallic elements. A review of their distribution, ecology and phytochemistry. Biorecovery 1: 81-126.

Baker A.J.M., Proctor J., van Balgooy M.M.J., Reeves R.D. (1992). Hyperaccumulation of nickel by the flora of the ultramafics of Palawan, Republic of the Philippines. In: Baker AJM, Proctor J, Reeves RD (eds) The vegetation of ultramafic (serpentine) soils, 2nd edn. Intercept, Andover, pp 291-304

Becquer T., Bourdon E., Pétard J. (1995). Disponibilité du nickel le long d'une toposéquence de sols développés sur roches ultramafiques de NouvelleCalédonie. Comptes Rendus de l'Académie des Sciences. Série 2a ;321:585-592.

Bert V., Macnair M.R., De Laguerie P., et al. (2000). Zinc tolerance and accumulation in metallicolous and nonmetallicolous populations of Arabidopsis halleri (Brassicaceae). New Phytologist 146: 225-233.

Boyd R.S. (2012). Plant defense using toxic inorganic ions: conceptual models of the defensive enhancement and joint effects hypotheses. Plant Science 195 88-95.

Boyd R.S., Martens S. (1994). Nickel hyperaccumulated by Thlaspi montanum var. montanum is acutely toxic to an insect herbivore. Oikos 70: 21-25.

Cabot C, Martos S, Llugany M, Gallego B, Tolrà R, Poschenrieder C. A role for zinc in plant defense against pathogens and herbivores. Frontiers in Plant Science. 2019;10:1171.

Caldelas C., Weiss D.J. (2017). Zinc homeostasis and isotopic fractionation in plants: a review. Plant and Soil 411: 17-46.

Clemens S. (2019). Metal ligands in micronutrient acquisition and homeostasis. Plant, Cell and Environment 42:2902-2912.

Corso M., García de la Torre V.S. (2020). Biomolecular approaches to understanding metal tolerance and hyperaccumulation in plants. Metallomics 12:840-859.

Deng T-H-B., Cloquet C., Tang Y-T., et al. (2014). Nickel and zinc isotope fractionation in hyperaccumulating and nonaccumulating plants. Environmental Science \& Technology 48:11926-11933.

Echevarria G (2021) Genesis and behaviour of ultramafic soils and consequences for nickel biogeochemistry. In: van der Ent A, Echevarria G, Baker AJM, More $J$ (eds) Agromining: extracting unconventional resources from plants, mineral resource reviews series. Springer, Cham, pp 215-238

Estrade N, Cloquet C, Echevarria G, et al. (2015) Weathering and vegetation controls on nickel isotope fractionation in surface ultramafic environments (Albania). Earth and Planetary Science Letters 423:24-35.

Fujii T., Moynier F., Blichert-Toft J., Albarède F. (2014). Density functional theory estimation of isotope fractionation of $\mathrm{Fe}, \mathrm{Ni}, \mathrm{Cu}$, and $\mathrm{Zn}$ among species relevant to geochemical and biological environments. Geochimica et Cosmochimica Acta 140: 553-576.

Hammond J.P., Bowen H.C., White P.J., et al. (2006). A comparison of the Thlaspi caerulescens and Thlaspi arvense shoot transcriptomes. New Phytologist 170 239-260.

Hanikenne M., Nouet C. (2011). Metal hyperaccumulation and hypertolerance: a model for plant evolutionary genomics. Current Opinion in Chemical Biology 14: 252-259.

Hanikenne M., Talke I.N., Haydon M.J., et al. (2008). Evolution of metal hyperaccumulation required cis-regulatory changes and triplication of HMA4. Nature 453: 391.

John SG, Geis RW., Saito M.A., Boyle E.A. (2007). Zinc isotope fractionation during high-affinity and low-affinity zinc transport by the marine diatom Thalassiosira oceanica. Limnology and Oceanography 52: 2710-2714.
Jouvin D., Louvat P., Juillot F., Maréchal C.N., Benedetti M.F. (2009). Zinc isotopic fractionation: why organic matters. Environmental Science and Technology 43: 5747-5754

Jouvin D., Weiss D.J., Mason T.F.M., Bravin M.N., Louvat P., Zhao F., Ferec F. Hinsinger P., Benedetti MF. (2012). Stable isotopes of Cu and Zn in higher plants: Evidence for Cu reduction at the root surface and two conceptual models for isotopic fractionation processes. Environmental Science and Technology 46: 2652-2660.

Krämer U., Talke I.N., Hanikenne M. (2007). Transition metal transport. FEBS Letters 581: 2263-2272.

Kukier U., Chaney R.L. (2001). Amelioration of nickel phytotoxicity in muck and mineral soils. Journal of Environmental Quality 30, 1949-1960.

Lin Y-F., Severing E.l., Lintel Hekkert te B., et al. (2014). A comprehensive set of transcript sequences of the heavy metal hyperaccumulator Noccaea caerulescens. Frontiers in Plant Science 5:261.

Lin W., Xiao T., Wu Y., et al. (2012). Hyperaccumulation of zinc by Corydalis davidii in Zn-polluted soils. Chemosphere 86: 837-842.

Lindsay W.L., Norvell W.A. (1978). Development of a DTPA soil test for zinc, iron, manganese, and copper. Soil Science Society of America Journal 42: 421-428

Manara A., Fasani E., Furini A., DalCorso G. (2020). Evolution of the metal hyperaccumulation and hypertolerance traits. Plant, Cell \& Environment 43: 2969-2986.

Marechal C., Telouk P., Albarede F. (1999). Precise analysis of copper and zinc isotopic compositions by plasma-source mass spectrometry. Chemical Geology 156: 251-273.

Merlot S., Sanchez Garcia de la Torre V., Hanikenne M. (2021). Physiology and molecular biology of trace element hyperaccumulation. In: van der Ent A., Baker A.J.M., Echevarria G., Simonnot M-O., Morel J.L. (eds) Agromining: Farming for Metals. Mineral Resource Reviews. Springer, Cham. pp. 155-181.

Moynier F., Pichat S., Pons M-L., Fike D., Balter V., Albarède F. (2009). Isotopic fractionation and transport mechanisms of $\mathrm{Zn}$ in plants. Chemical Geology 267, 125-130

Moynier F., Vance D., Fujii T., Savage P. (2017). The isotope geochemistry of zinc and copper. Reviews in Mineralogy and Geochemistry 82: 543-600.

Nkrumah P.N., Echevarria G., Erskine P.D., van der Ent A. (2018). Contrasting nickel and zinc hyperaccumulation in subspecies of Dichapetalum gelonioides from Southeast Asia. Scientific Reports 8:9659.

Opfergelt S., Cornélis J.T., Houben D., Givron C., Burton K.W., Mattielli N. (2017). The influence of weathering and soil organic matter on $\mathrm{Zn}$ isotopes in soils. Chemical Geology 466: 140-148.

Page V., Feller U. (2015). Heavy metals in crop plants: transport and redistribution processes on the whole plant level. Agronomy 5: 447-463.

Papoyan A., Kochian L.V. (2004). Identification of Thlaspi caerulescens genes that may be involved in heavy metal hyperaccumulation and tolerance. Characterization of a novel heavy metal transporting ATPase. Plant Physiology 136: 3814-3823.

Paul A.L.D., Isnard S., Wawryk C.M., Erskine P.D., Echevarria G., Baker A.J.M., Kirby J. K., van der Ent A. (2021). Intensive cycling of nickel in a New Caledonian forest dominated by hyperaccumulator trees. Plant Journal. doi: https://doi. org/10.1111/tpj.15362.

Pollard A.J., Baker A.J.M. (1997). Deterrence of herbivory by zinc hyperaccumulation in Thlaspi caerulescens (Brassicaceae). New Phytologist 135: 655-658.

Punt W. (1975). Pollen morphology of the Dichapetalaceae with special reference to evolutionary trends and mutual relationships of pollen types. Review of Palaeobotany and Palynology 19: 1-97.

Ratié G, Quantin C, Maia De Freitas A, Echevarria G, Ponzevera E, Garnier J. (2019). The behavior of nickel isotopes at the biogeochemical interface between ultramafic soils and Ni accumulator species. Journal of Geochemical Exploration 196:182-191.

Reeves R.D. (1988). Nickel and zinc accumulation by species of Thlaspi L., Cochlearia L., and other genera of the Brassicaceae. Taxon 1:309-318.

Reeves R.D. (2003). Tropical hyperaccumulators of metals and their potential for phytoextraction. Plant and Soil 249: 57-65.

Reeves R.D., Baker A.J.M. (2000). Metal-accumulating plants. In: Raskin I, Ensley BD (eds). Phytoremediation of toxic metals: using plants to clean up the environment. John Wiley \& Sons, New York, pp 193-229.

Reeves R.D., Baker A.J.M., Jaffré T., Erskine P.D., Echevarria G., van der Ent A. (2018). A global database for hyperaccumulator plants of metal and metalloid trace elements. New Phytologist 218: 407-411. 
Reeves R.D., Brooks R.R. (1983). European species of Thlaspi L. (Cruciferae) as indicators of nickel and zinc. Journal of Geochemical Exploration 18: 275283.

Reeves R.D., Schwartz C., Morel J.L. et al. (2001). Distribution and metalaccumulating behavior of Thlaspi caerulescens and associated metallophytes in France. International Journal of Phytoremediation 2: 145-172.

Ricachenevsky F.K., Punshon T., Salt D.E. et al. (2021). Arabidopsis thaliana zinc accumulation in leaf trichomes is correlated with zinc concentration in leaves. Scientific Reports 11: 5278 (2021). https://doi.org/10.1038/s41598-02184508-y

Schvartzman M.S., Corso M., Fataftah N., Scheepers M., Nouet C., Bosman B. Carnol M., Motte P., Verbruggen N., Hanikenne, M. (2018). Adaptation to high zinc depends on distinct mechanisms in metallicolous populations of Arabidopsis halleri. New Phytologist 218:269-282.

Schwartz C., Echevarria G., Morel J.L. (2003). Phytoextraction of cadmium with Thlaspi caerulescens. Plant and Soil 249: 27-35.

Smolders E., Versieren L., Shuofei D., Mattielli N., Weiss D., Petrov I., Degryse F. (2013). Isotopic fractionation of $\mathrm{Zn}$ in tomato plants suggests the role of root exudates on Zn uptake. Plant and Soil 370, 605-613.

Sossi P., Halverson G., Nebel O., Eggins S. (2014). Combined separation of Cu, Fe and $\mathrm{Zn}$ from rock matrices and improved analytical protocols for stable isotope determination. Geostandards and Geoanalytical Research 39: $129-$ 149.

Stein R.J., Höreth S., Melo J.R.F. et al. (2017). Relationships between soil and leaf mineral composition are element specific, environment-dependent and geographically structured in the emerging model Arabidopsis halleri. New Phytologist 213: 1274-1286.

Stolpe C., Giehren F., Krämer U., Müller C. (2017). Both heavy metal-amendment of soil and aphid-infestation increase $\mathrm{Cd}$ and $\mathrm{Zn}$ concentrations in phloem exudates of a metal-hyperaccumulating plant. Phytochemistry 139, 109-117.

Talke I.N., Hanikenne M., Krämer U. (2006). Zinc-dependent global transcriptional control, transcriptional deregulation, and higher gene copy number for genes in metal homeostasis of the hyperaccumulator Arabidopsis halleri. Plant Physiology 142: 148-167.

Tang Y.T., Cloquet C., Sterckeman T., Echevarria G., Carignan J., Qiu R.L., Morel J-L. (2012). Fractionation of stable zinc isotopes in the field-grown zinc hyperaccumulator Noccaea caerulescens and the zinc-tolerant plant Silene vulgaris. Environmental Science and Technology 46: 9972-9979.

Tang Y.T., Cloquet C., Deng T.H.B., Sterckeman T., Echevarria G., Yang W.J., Morel J. L., Qiu R.L. (2016). Zinc isotope fractionation in the hyperaccumulator Noccaea caerulescens and the nonaccumulating plant Thlaspi arvense at low and high Zn supply. Environmental Science and Technology 50: 8020-8027.

US Environmental Protection Agency (1996). Method 3052: Microwave assisted acid digestion of siliceous and organically based matrices. SW-846.

van de Mortel J.E., Villanueva L.A., Schat H., et al. (2006). Large expression differences in genes for iron and zinc homeostasis, stress response, and lignin biosynthesis distinguish roots of Arabidopsis thaliana and the related metal hyperaccumulator Thlaspi caerulescens. Plant Physiology 142: 1127-1147.

van der Ent A., Baker A.J.M., Reeves R.D., et al. (2013). Hyperaccumulators of metal and metalloid trace elements: facts and fiction. Plant and Soil 362: 319-334.

van der Ent A., Przybyłowicz W.J., de Jonge M.D., Harris H.H., Ryan C.G., Tylko G., Paterson D.J., Barnabas A.D., Kopittke P.M., Mesjasz-Przybyłowicz J. (2017). Xray elemental mapping techniques for elucidating the ecophysiology of hyperaccumulator plants. New Phytologist 218: 432-452.

van der Ent A., Mulligan D.R., Repin R., Erskine P.D. (2018). Foliar elementa profiles in the ultramafic flora of Kinabalu Park (Sabah, Malaysia). Ecological Research 33: 659-674

Verbruggen N., Hermans C., Schat H. (2009). Molecular mechanisms of metal hyperaccumulation in plants. New Phytologist 181: 759-776.

Viers J., Oliva P., Nonell A., Gélabert A., Sonke J.E., Freydier R., Gainville R., Dupré B. (2007). Evidence of $\mathrm{Zn}$ isotopic fractionation in a soil-plant system of a pristine tropical watershed (Nsimi, Cameroon). Chemical Geology 239: $124-$ 137.

Viers J., Prokushkin A.S., Pokrovsky O.S., Kirdyanov A.V., Zouiten C., Chmeleff J., Meheut M., Chabaux F., Oliva P., Dupré B. (2015). Zn isotope fractionation in a pristine larch forest on permafrost-dominated soils in Central Siberia. Geochemical Transactions 16: 1-15.

Weiss D.J., Rausch N., Mason T.F., Coles B.J., Wilkinson J.J., Ukonmaanaho L., Arnold T., Nieminen T.M. (2007). Atmospheric deposition and isotope biogeochemistry of zinc in ombrotrophic peat. Geochimica et Cosmochimica Acta 71: 3498-3517.
Wiggenhauser M., Bigalke M., Imseng M., Keller A., Archer C., Wilcke W., Frossard E. (2018). Zinc isotope fractionation during grain filling of wheat and a comparison of zinc and cadmium isotope ratios in identical soil-plant systems. New Phytologist 219: 195-205.

Zelano IO, Cloquet C, van der Ent A, Echevarria G, Gley R, Landrot G, Pollastri S, Fraysse F, Montargès-Pelletier E (2020) Coupling nickel chemical speciation and isotope ratios to decipher nickel dynamics in the Rinorea cf. bengalensis-soil system in Malaysian Borneo. Plant and Soil 454:225-243.

\section{Publisher's Note}

Springer Nature remains neutral with regard to jurisdictional claims in published maps and institutional affiliations.
Ready to submit your research? Choose BMC and benefit from:

- fast, convenient online submission

- thorough peer review by experienced researchers in your field

- rapid publication on acceptance

- support for research data, including large and complex data types

- gold Open Access which fosters wider collaboration and increased citations

- maximum visibility for your research: over $100 \mathrm{M}$ website views per year

At $\mathrm{BMC}$, research is always in progress.

Learn more biomedcentral.com/submissions 